Short Communication

Open Access

\title{
Comparative distribution of bacterial contaminants of packaged and unpackaged polyherbal products sold in Nnewi, Nigeria
}

\author{
*Udeogu, C. V., Agbakoba, N. R., and Chukwuma, G. O. \\ Medical Microbiology Unit, Department of Medical Laboratory Science \\ Nnamdi Azikiwe University, Nnewi, Anambra State, Nigeria \\ Correspondence to: chidozie.udeogu@yahoo.com
}

\begin{abstract}
:
Background: The use of herbal medicine continues to remain popular despite advances in orthodox medicine largely as a result of affordability and availability. However, contaminated and potentially toxic polyherbal preparations remain a public health challenge despite regulations instituted by concerned agencies in Nigeria. The objective of this study was to determine and compare the bacterial contaminants of different polyherbal products sold in Nnewi, Nigeria

Methodology: This study evaluated the bacteriological profile of 22 packaged and 22 unpackaged polyherbal preparations sold in Nnewi, Nigeria. The samples were collected from different herbal medicine shops in Nnewi by simple random sampling and were assayed for comparative bacterial loads with chromogenic media and their total viable counts evaluated following standard method for microbial load analysis.

Results: Bacterial contaminants were isolated from 9 of $22(40.9 \%)$ packaged polyherbal samples while 13 of 22 $(59.1 \%)$ samples were bacteriologically sterile. For the unpackaged polyherbal, bacterial contaminants were isolated from 18 of $22(81.8 \%)$ samples while 4 of $22(18.2 \%)$ were bacteriologically sterile (OR $0.1538, p=0.0122)$. The most frequently isolated bacterial contaminant in the packaged polyherbal samples was Enterococcus faecalis with $33.3 \%(6 / 18)$ while Salmonella sp was the least frequently isolated with 5.6\% (1/18). For the unpackaged polyherbals, the most frequently isolated bacterial contaminant was Staphylococcus aureus with 25\% (7/28) while Salmonella sp and $E$. faecalis were the least frequently isolated with $10.7 \%(3 / 28)$ each. The median total viable count of the packaged group of the polyherbal products was $1.48 \times 10^{6} \mathrm{CFU} / \mathrm{ml}$, while the median total viable count for unpackaged group of polyherbals was $1.95 \times 10^{6} \mathrm{CFU} / \mathrm{ml}$.

Conclusion: This study shows that many polyherbal products sold in Nnewi are potentially contaminated with bacterial agents. It is therefore imperative that herbal medicine practitioners be enlightened on hygienic ways of preventing microbial contamination during polyherbal production.
\end{abstract}

Keywords: Bacterial contaminants, herbal products, Nnewi, Nigeria

Received January 21, 2020; Revised May 14, 2020; Accepted May 17, 2020

Copyright 2020 AJCEM Open Access. This article is licensed and distributed under the terms of the Creative Commons Attrition 4.0 International License <a rel="license" href="http://creativecommons.org/licenses/by/4.0/", which permits unrestricted use, distribution and reproduction in any medium, provided credit is given to the original author(s) and the source.

\section{Distribution comparative des contaminants bactériens des produits polyherbal emballés et non emballés vendu à Nnewi, Nigeria}

\author{
*Udeogu, C. V., Agbakoba, N. R., et Chukwuma, G. O. \\ Unité de microbiologie médicale, Département des sciences de laboratoire médical \\ Université Nnamdi Azikiwe, Nnewi, État d'Anambra, Nigéria \\ Correspondance à: chidozie.udeogu@yahoo.com
}

\section{Abstrait:}

Contexte: L'utilisation de la phytothérapie continue de rester populaire malgré les progrès de la médecine orthodoxe en grande partie en raison de l'abordabilité et de la disponibilité. Cependant, les préparations à base de plantes contaminées et potentiellement toxiques restent un problème de santé publique malgré les réglementations mises en place par les agences concernées au Nigeria. L'objectif de cette étude était de déterminer et de comparer les 
contaminants bactériens de différents produits polyherbal vendus à Nnewi, Nigeria

Méthodologie: Cette étude a évalué le profil bactériologique de 22 préparations polyherbal emballées et 22 non emballées vendues à Nnewi, Nigeria. Les échantillons ont été collectés dans différents magasins de plantes médicinales de Nnewi par simple échantillonnage aléatoire et ont été analysés pour les charges bactériennes comparatives avec les milieux chromogènes et leurs dénombrements viables totaux évalués selon la méthode standard pour l'analyse de la charge microbienne.

Résultats: Des contaminants bactériens ont été isolés dans 9 des 22 échantillons polyherbal emballés (40,9\%) tandis que 13 des 22 échantillons $(59,1 \%)$ étaient bactériologiquement stériles. Pour le polyherbal non emballé, des contaminants bactériens ont été isolés de 18 des 22 échantillons (81,8\%) tandis que 4 des 22 (18,2\%) étaient bactériologiquement stériles (OR $0,1538, p=0,0122$ ). Le contaminant bactérien le plus fréquemment isolé dans les échantillons polyherbal emballés était Enterococcus faecalis avec 33,3\% (6/18) tandis que Salmonella sp était le moins fréquemment isolé avec $5,6 \%(1 / 18)$. Pour les polyherbals non emballés, le contaminant bactérien le plus fréquemment isolé était Staphylococcus aureus avec 25\% (7/28) tandis que Salmonella sp et E. faecalis étaient les moins fréquemment isolés avec $10,7 \%(3 / 28)$ chacun. Le nombre total viable médian du groupe emballé des produits polyherbal était de $1,48 \times 10^{6} \mathrm{UFC} / \mathrm{ml}$, tandis que le nombre total viable médian pour le groupe non emballé de polyherbales était $1,95 \times 10^{6} \mathrm{UFC} / \mathrm{ml}$.

Conclusion: Cette étude montre que de nombreux produits polyherbal vendus à Nnewi sont potentiellement contaminés par des agents bactériens. Il est donc impératif que les praticiens en phytothérapie soient éclairés sur les moyens hygiéniques de prévenir la contamination microbienne pendant la production de polyherbes.

Mots-clés: Contaminants bactériens, produits à base de plantes, Nnewi, Nigéria

\section{Introduction:}

Herbal medicine is a medication made from herbs and has long been used as a source of alternative medicines in developed, developping and underdeveloped countries. Throughout the ages, humans have turned to herbal medicine for healing. All societies have folk medicine traditions that include the use of plants and plant products. Many licensed drugs used today in conventional medicine originated from herbal products.

The World Health Organization (WHO) estimates that about 4 billion or at least $80 \%$ of the world's population use herbal preparations for some aspects of primary health care (10). In Nigeria, herbal therapy remains a popular alternative in many traditional communities where orthodox medicine is not affordable (2). Herbal medicine practitioners in Nigeria use various herbal preparations to treat various types of ailments including diarrhoea, urinary tract infections, typhoid fever and skin diseases (8). Unfortunately, many of these herbal medicine practitioners do not follow hygienic procedures in preventing microbial contaminants during production of their polyherbal products. The study is designed to comparatively evaluate bacteriological contaminants of packaged and unpackaged polyherbals sold in Nnewi, Nigeria.

\section{Materials and method:}

\section{Collection of polyherbal samples}

A total of 44 samples of liquid formulations of the polyherbals produced in Nigeria were purchased from 16 different herbal shops and trado-medical hawkers, who were selected by simple random sampling within Nnewi town. The samples of the packaged polyherbal preparations $(n=22)$ were purchased while samples of the unpackaged extemporaneous polyherbal preparations $(n=22)$ were collected in polythene bags that are used to dispense products to customers by the herbal medicine practitioners. All samples were labeled and immediately transported to the Faculty of Health Science Laboratory of the Nnamdi Azikiwe University, Okofia, Nnewi.

\section{Estimation of total viable count of bacteria}

A tenfold dilution of each sample of polyherbal was achieved by adding $1 \mathrm{ml}$ of each sample to $9 \mathrm{ml}$ of sterile normal saline in the first test tube of a row of 10 sterile tubes. One (1) $\mathrm{ml}$ from the first tubes on each row was then transferred to the $2^{\text {nd }}$ test tube after proper mixing continuing up to the $10^{\text {th }}$ tube where one (1) $\mathrm{ml}$ of the mixture was discarded to achieve a $1 / 10^{1}$ to $1 / 10^{10}$ dilutions. One (1) $\mathrm{ml}$ of the dilution from each test tube was then transferred into a sterile Petri dish and molten nutrient agar was added, the constituents were well mixed and incubated aerobically at $37^{\circ} \mathrm{C}$ for 24 hours. The number of colonies on each plate was counted and the mean for each sample was established and recorded as the mean colony forming units (CFU) per ml.

\section{Isolation and identification of bacterial contaminants in the polyherbal preparations.}

The isolation and identification of the bacterial agents was done by culture on two commercial chromogenic media; CHROMagar ${ }^{\mathrm{TM}}$ Orientation and HARDYCHROM ${ }^{\mathrm{TM}}$ SS NOPRO agar, which have been validated to have positive and negative predictive values of $99.3 \%$ and $100 \%$ respectively for the isolation and identification of the bacterial organisms such as Klebsiella pneumoniae, Enterococcus faecalis, Staphylococcus aureus, Staphylococcus epidermidis, Escherichia coli, Proteus sp, Salmonella sp, Citrobacter sp, Serratia marcescens, Providencia sp, Acinetobacter sp, and 
Pseudomonas aeruginosa which are common contaminants in polyherbal preparations $(1,5)$. The media were prepared according to the manufacturer's instructions.

Briefly, labeled individual samples of both the packaged and unpackaged herbals were well mixed to ensure complete homogenization before culture. A loopful of each of the samples was streaked on the prepared agar plates using sterile wire loop. Incubation was done aerobically at $37^{\circ} \mathrm{C}$ for 24 hours. A sterile non-inoculated plate was also placed in the incubator for quality control during incubation (3). Plates were read after 24 hours and bacteria were identified by their peculiar and different colony colours and chromogenic attributes using the colour charts as a guide (7), in determining the bacterial isolates (1). The identification parameters of bacterial colonies on the media based on colour are; Klebsiella sp colonies appeared metallic blue, Enterococcus faecalis colonies as red, Proteus mirabilis colonies as clear and brown halo, and Salmonella spp as pink.

\section{Analysis of data}

The data were presented in frequency tables and statistical analysis performed with IBM SPSS 20.0 version. Chi square test was used to measure association of bacterial contamination with packed and unpackaged polyherbals, and $p$ value less than 0.05 was considered to be statistically significant.

\section{Results:}

The frequency of distribution of bacterial contaminants in the packaged and unpackaged polyherbal samples is shown in Table 1.
Bacterial contaminants were isolated from 9 of 22 (40.9\%) packaged polyherbal samples while 13 of $22(59.1 \%)$ samples were bacteriologically sterile. For the unpackaged polyherbals, bacterial contaminants were isolated in $18 / 22(81.8 \%)$ samples while $4 / 22(18.2 \%)$ were bacteriologically sterile (OR $0.1538, p$ $=0.0122$ ). Of the 9 positive samples in the packaged polyherbals, a total of 18 bacterial isolates were recovered, $E$. faecalis was the most frequent with $33.3 \%(6 / 18)$, followed by S. aureus $16.7 \%$, E. coli $16.7 \%$, Proteus sp $16.7 \%, K$. pneumoniae $11.1 \%$ and Salmonella sp $5.6 \%$. Of the 18 positive samples in the unpackaged polyherbals, a total of 28 bacterial isolates were recovered, $S$. aureus was the most frequent with $25 \%(7 / 28)$, followed by $K$. pneumoniae $17.9 \%$, E. coli $17.9 \%$, Proteus sp $17.9 \%$, E. faecalis $10.7 \%$ and Salmonella sp 10.7\% (Table 1).

Table 2 shows the distribution of the polyherbal products from the 16 herbal shops and trado-medical hawkers, and the bacteria isolates recovered from those positive. Table 3 shows the total viability count (TVC) for each of the packaged herbal product that cultured positive for bacteria with a mean TVC of $1.48 \mathrm{x}$ $10^{6} \mathrm{CFU} / \mathrm{ml}$, while Table 4 shows the TVC for each of the unpackaged herbal product that cultured positive for bacteria, with a mean TVC of $1.85 \times 10^{6} \mathrm{CFU} / \mathrm{ml}$.

\section{Discussion:}

Data obtained from this study showed that bacterial agents such as $K$. pneumoniae, $E$. faecalis, S. aureus, E. coli, P. mirabilis and Salmonella sp were isolated at varying frequencies in both groups of polyherbals. These

Table 1: Frequency distribution of bacterial isolates in packaged and unpackaged polyherbal samples

\begin{tabular}{|c|c|c|c|c|}
\hline $\begin{array}{l}\text { No of polyherbals/ } \\
\text { bacterial isolates }\end{array}$ & $\begin{array}{l}\text { Packaged }(\%) \\
(n=22)\end{array}$ & $\begin{array}{l}\text { Unpackaged }(\%) \\
(n=22)\end{array}$ & $\mathrm{X}^{2}$ & $P$ \\
\hline No bacteria isolate & $13(59.1)$ & $4(18.8)$ & 7.8 & $0.01 *$ \\
\hline $\begin{array}{l}\text { No positive for bacterial } \\
\text { isolate }\end{array}$ & $9(40.9)$ & $18(81.2)$ & & \\
\hline Klebsiella pneumoniae & $2(11.1)$ & $5(17.9)$ & & \\
\hline Enterococcus faecalis & $6(33.3)$ & $3(10.7)$ & & \\
\hline Staphylococcus aureus & $3(16.7)$ & $7(25)$ & & \\
\hline Escherichia coli & $3(16.7)$ & $5(17.9)$ & & \\
\hline Proteus sp & $3(16.7)$ & $5(17.9)$ & & \\
\hline Salmonella sp & $1(5.6)$ & $3(10.7)$ & & \\
\hline Total isolates & $18(100)$ & $28(100)$ & & \\
\hline
\end{tabular}


Table 2: Distribution of bacterial contaminants in polyherbals purchased at the herbal shops

\begin{tabular}{|c|c|c|}
\hline Herbal shops & Polyherbals & Bacterial isolates \\
\hline Dan-Iyke & Katoka, Ruzu bitters, Yoyo bitters & No growth \\
\hline Blessed Mother & Blood purifier, Super bitters & No growth \\
\hline Dr Chiagozie & $\begin{array}{c}\text { Nando mixture, Super bitters, Mako cleanser, } \\
\text { Super 7, Ruzu bitters }\end{array}$ & Enterococcus faecalis \\
\hline Panx & Goko cleanser, dukun care, Dr Igah cleanser & E. coli, Klebsiella sp, E. faecalis, S. aureus \\
\hline Fesco & Deep root, Bitterkinga & No growth \\
\hline Dr Agnes & J.M.I herbal, Museya, Jalin herbal & E. faecalis, Klebsiella sp, E. coli, Proteus sp \\
\hline Eze & Eze herbal mixture, new beta cleanser & E. coli, Proteus sp \\
\hline Dr Benbella & Weifa body defense & No growth \\
\hline Baba Oyo & Olori herbal mixture & E. faecalis, S. aureus, Proteus sp \\
\hline Yemi & Anti-pile, Anti-diabetic, fibroid & $\begin{array}{c}\text { E. coli, Klebsiella sp, E. faecalis } \\
\text { Salmonella sp }\end{array}$ \\
\hline Dan Obitube & $\begin{array}{c}\text { Convulsion formula, general well-being, blood } \\
\text { booster, energy booster }\end{array}$ & E. coli, E. faecalis \\
\hline Titi & Fertility preparation, Laxative preparation & S. aureus, Proteus sp \\
\hline Barakat & Anti-ulcer, STI preparation, Abdominal preparation & S. aureus, Proteus sp \\
\hline Laide & Skin infection, menstruation prep & Proteus sp \\
\hline Baba Osun & Male fertility, sexual health, anti-pile, back pain & E. coli, S. aureus, Klebsiella sp, Salmonella sp \\
\hline Sunny & Anti-gonorrhoea, STD preparation, anti-malaria & E. coli, Klebsiella sp \\
\hline
\end{tabular}

Table 3: Total Viable counts in packaged polyherbal samples and their bacteriological safety

\begin{tabular}{|c|c|c|}
\hline Packaged polyherbals & $\begin{array}{c}\text { Total Viable count } \\
\text { (CFU/mI) }\end{array}$ & $\begin{array}{c}\text { Bacteriological Safety } \\
\text { Level }\left(10^{5}\right)\end{array}$ \\
\hline Deep Root & No Isolate & Safe \\
\hline Blood purifier & No Isolate & Safe \\
\hline Jalin herbal mixture & $1.5 \times 10^{6}$ & Unsafe \\
\hline J.M.I herbal mixture & $3.6 \times 10^{6}$ & Unsafe \\
\hline Mako Cleanser & No Isolate & Safe \\
\hline Super 7 & $1.4 \times 10^{6}$ & Unsafe \\
\hline Museya bitters & No Isolate & Safe \\
\hline Dr Igah Bitter cleanser & $0.7 \times 10^{6}$ & Unsafe \\
\hline Goko Cleanser & No Isolate & Safe \\
\hline New Beta cleanser & No Isolate & Safe \\
\hline Infection destroyer & $1.3 \times 10^{6}$ & Unsafe \\
\hline Dr sunny Gonorrhea herbal & $1.8 \times 10^{6}$ & Unsafe \\
\hline Dukun Care & $1.7 \times 10^{6}$ & Unsafe \\
\hline Katoka Mixture & No Isolate & Safe \\
\hline Eze herbal & $3.2 \times 10^{6}$ & Unsafe \\
\hline Dr Nando & No Isolate & Safe \\
\hline Super bitters & No Isolate & Safe \\
\hline Ruzu bitters & No Isolate & Safe \\
\hline Weifa body defense & No Isolate & Safe \\
\hline Bitterkinga & No Isolate & safe \\
\hline Yoyo bitters & No Isolate & Safe \\
\hline \multicolumn{3}{|c|}{ Mean Total Viable count (TVC) $=1.4845 \pm 122.17 \times 10^{6}$} \\
\hline
\end{tabular}


Table 4: Total viable counts in unpackaged polyherbal samples and their bacteriological safety

\begin{tabular}{|c|c|c|}
\hline Unpackaged Polyherbals & $\begin{array}{c}\text { Total Viable Counts } \\
\text { (CFU/mI) }\end{array}$ & $\begin{array}{c}\text { Bacteriological safety } \\
\text { Level } 10^{5}\end{array}$ \\
\hline Anti-malaria preparation & & Unsafe \\
\hline Convulsion formula & $3.3 \times 10^{6}$ & Unsafe \\
\hline General Well-being formula & No Isolate & Safe \\
\hline Anti-Pile preparation & $2.3 \times 10^{6}$ & Unsafe \\
\hline Anti-Diabetic preparation & No Isolate & Safe \\
\hline Fertility preparation & $2.1 \times 10^{6}$ & Unsafe \\
\hline Blood booster & $1.9 \times 10^{6}$ & Unsafe \\
\hline Back pain preparation & $3.1 \times 10^{6}$ & Unsafe \\
\hline Laxative preparation & $8.9 \times 10^{6}$ & Unsafe \\
\hline General well-being & $1.8 \times 10^{6}$ & Unsafe \\
\hline Anti-Gonorrhoea preparation & $2.9 \times 10^{6}$ & Unsafe \\
\hline Anti-ulcer preparation & $1.6 \times 10^{6}$ & Unsafe \\
\hline Anti-malaria preparation & $2.0 \times 10^{6}$ & Unsafe \\
\hline Male fertility preparation & $1.8 \times 10^{6}$ & Unsafe \\
\hline Sexual health preparation & $3.7 \times 10^{6}$ & Unsafe \\
\hline General wellness & $3.0 \times 10^{6}$ & Unsafe \\
\hline STI preparation & $3.2 \times 10^{6}$ & Unsafe \\
\hline $\begin{array}{c}\text { Abdominal disturbance } \\
\text { preparation }\end{array}$ & No Isolate & Safe \\
\hline Skin infection preparation & No Isolate & Safe \\
\hline Fibroid preparation & $1.2 \times 10^{6}$ & Unsafe \\
\hline Menstruation preparation & $1.9 \times 10^{6}$ & Unsafe \\
\hline Energy booster & $1.7 \times 10^{6}$ & Unsafe \\
\hline
\end{tabular}

results are similar with the findings of Esimone et al., (4) and Tatfeng et al., (9), both of whom detected bacterial agents at varying frequencies in herbals and polyherbals samples in Nigeria. The predominance of $E$. faecalis and S. aureus in the packaged and unpackaged herbals respectively is in consonance with the study by Esimone et al., (4) who investigated the microbiological quality of liquid herbal preparations in south-eastern Nigeria and isolated arrays of microbial contaminants including $S$. aureus and $E$. faecalis as the most predominant bacterial contaminants of herbal medicines.

The higher frequency of contamination observed in the unpackaged group of polyherbals $(81.8 \%)$ and higher median total viable count (TVC) compared to those of the packaged group may be attributable to contamination due to lack of standardization and quality control, poor personnel hygiene and handling, and use of contaminated water and raw materials (4). These findings could also be due to the fact that the packaged polyherbal products are comparatively better regulated by government agencies such as the National Agency for Food and Drug Administration and Control (NAFDAC) and the State Ministries of Health who usually mandate the manufacturers of packaged polyherbals to adopt some level of good manufacturing procedure, safe handling measures during production and quality control (6).
This study shows that many polyherbal products sold in Nnewi are potentially contaminated by bacterial agents, some of which are potential pathogens of man. It is imperative that herbal medicine practitioners be enlightened on hygienic ways of preventing microbial contamination during polyherbal production.

\section{References:}

1. Berger, D., Clasen, R., Cuna, A., Knox, J., and Hardy, J. Evaluation of Novel Chromogenic medium for the isolation and differentiation of Salmonella and Shigella spp. Presented at the $111^{\text {th }}$ General Meeting of American society for Microbiology, New Orleans, LA. 2011: 3601

2. Burkill H. M. The Useful Plants of West Africa $3^{\text {rd }}$ ed London. Royal Botanical Gardens; Kew, Richmond, United Kingdom. 1997: 377.

3. Cowan, S. T., and Steel, K. J. Manual for identification of medical bacteria. Vol 2, $2^{\text {nd }}$ edn; Cambridge University Press; London. 1974: 15-47.

4. Esimone, C. O., Shah, K. F., and Ikejide, F. C. Microbial quality of herbal preparations marketed in South Eastern Nigeria. Journal of Natural Remedies. 2001: 2 (1): 42-48.

5. Filius, P., Van Netten., D., Roovers, J., Vulto, G., Gyssens, C., Verbrugh, A., and Endtz, P. Comparative evaluation of three chromogenic agars for detection and rapid identification of aerobic gram-negative bacteria in the normal intestinal microflora. Clinical Microbiology and Infection. 2003: 9 (9): 912-918.

6. National Agency for Food and Drug Administration and Control. Standard Operating Procedures (NAFDAC SOP). Determination of moisture contents. Yaba, Lagos: Central Drugs and Vaccine Control Laboratory (CDVCL); 2000: 1-2. 
7. Singh, A. K., and Bhunia, A. Optical scatter patterns facilitate rapid differentiation of Enterobacteriaceae on CHROMagar ${ }^{\mathrm{TM}}$ Orientation

media. Microb Biotechnol. 2016; 9 (1): 127 - 135 Sofowora, A. Medicinal plants and traditional medicine in Africa. Ibadan: Spectrum books Ltd (pub); 1993: 50-195.
9. Tatfeng, M., Ollama, H., and Ojo, O. Microbial burden of some herbal antimalarial marketed at Elele, Rivers State. J Afr Trad Compl Altern Med. 2010: 7(2): 149-152.

10. World Health Organization (WHO). Regulatory situation of herbal medicines: A worldwide review. Geneva: World Health Organization, 1998. 